Meta

Journal des traducteurs

Translators' Journal

\title{
Pencils to Processors (A Sort of Memoir)
}

\section{R. Clive Meredith}

Volume 37, numéro 2, juin 1992

URI : https://id.erudit.org/iderudit/003636ar

DOI : https://doi.org/10.7202/003636ar

Aller au sommaire du numéro

Éditeur(s)

Les Presses de l'Université de Montréal

ISSN

0026-0452 (imprimé)

1492-1421 (numérique)

Découvrir la revue

Citer cet article

Meredith, R. C. (1992). Pencils to Processors (A Sort of Memoir). Meta, 37(2),

379-383. https://doi.org/10.7202/003636ar

\section{Résumé de l'article}

L'auteur raconte comment il est devenu traducteur. Il expose ses souvenirs de vingt-sept ans de pratique traditionnelle et rend compte des changements survenus dans les méthodes de travail au cours de ces années. Il s'interroge sur son métier et fournit des conseils aux apprentis traducteurs.
Ce document est protégé par la loi sur le droit d'auteur. L’utilisation des services d’Érudit (y compris la reproduction) est assujettie à sa politique d'utilisation que vous pouvez consulter en ligne.

https://apropos.erudit.org/fr/usagers/politique-dutilisation/ 


\section{PENCILS TO PROCESSORS (A SORT OF MEMOIR)}

\section{Résumé}

L'auteur raconte comment il est devenu traducteur. Il expose ses souvenirs de vingt-sept ans de pratique traductionnelle et rend compte des changements survenus dans les méthodes de travail au cours de ces années. II s'interroge sur son métier et fournit des conseils aux apprentis traducteurs.

On May 31 1991, I left the Quebec Provincial Government after twenty-seven years as a translator. The notes which follow are based on observations and activities during those unforgettable years of challenge and enrichment..

In the autumn of 1963, a colleague at the Provincial Secretary's Department showed me an ad he'd clipped from the Montreal Gazette. Translators were wanted at the Legislative Assembly, to work from French into English.

"Translation! Hey, there's an idea! Never would have thought of it, but why not?'

I was sure I had all the qualifications listed in the ad, but more important, the salary offered was well above the pittance I was earning at the time (never mind that the only translation I'd done to date had been of a one-page c.v. for one of $\mathrm{my}$ professors)

The application was duly submitted and accepted, the prescribed exam written. On my arrival home, my wife asked me how things had gone. "Forget it. Just another dream down the tubes."

After a too-long interval, I learned that in fact I'd passed the exam, and was summoned to an oral interview.

After another too-long interval, my office telephone rang.

"Would you be willing to transfer to the Legislative Assembly next Monday?"

$$
* * *
$$

Even today, with twenty-seven years of practice under my belt, I sometimes find myself wondering how I ever gained admission to my profession. Certainly when I took that long-ago exam, I must have been the greenest candidate in the room. My motivation was strictly mercenary, and even after I'd been admitted to the staff of the Legislative Assembly, I kept telling myself that this was just a stop-gap measure, "until something better comes along."

Within six months, I was practically hooked, and becoming increasingly convinced that there was nothing better that could come along.
By dint of effort, encouragement and modest success, that conviction grew.

But there was so much to be learned! I had entered a world which until a few days previously I had scarcely known existed; a world replete with challenge...

Not everyone is able to plot the courses of the stars or to comprehend the workings of the cerebral cortex; similarly, not everyone is able to translate acceptably. Not even if he is fluent in two or more languages. Now, there is an affirmation which will come as a surprise to many. For the belief is still widespread among the uninitiated that as long as a person possesses even limited knowledge of two or more languages, that person has all it takes to be a translator, and not only that: he or she can reasonably be expected to translate into or out of any of those languages - at the drop of a hat and with equal proficiency. What naive, misguided thinking! Every day, we within the profession are witness to evidence which can refute this philosophy ten thousandfold. How long, I wonder, until it is eradicated?

Now what of the ability to translate? To what shall it be likened? And how, in a nutshell, can it be described?

The apostle Saint Paul numbers it among the gifts bestowed by the Holy Spirit. Consider the tenth verse of Chapter XII of his First Letter to the Church at Corinth:

... to another (is given) the working of miracles; to another prophecy... to another divers kinds of tongues; to another the interpretation of tongues..

Note how the Apostle draws a distinction between "knowledge" of "tongues" and the ability to "interpret" them. Paul realized back then what many do not: that while a person can "know" two or more languages, that person may be incapable of translating a single sentence from one into the other. And was it by merely fortuitous writing or by extreme foresight that he placed the interpreters of tongues in the same verse as the workers of miracles? For ours is surely a profession whose practitioners are called upon almost daily to perform an editorial miracle or two!

Others, more prosaically, would liken the ability to translate to an "ear" for music: either you have it or you haven't. Simplistic though that view may be, I remain rather partial to it. In fact, considering how "musical" so many of my colleagues are, I sometimes wonder whether the "car" and the ability to translate do not in fact complement each other.

Be all this as it may - be the ability to translate a gift from above or a gift from within one thing is certain: it is a gift never to be taken for granted: a gift to be constantly honed, refined, perfected; otherwise rot and mildew will surely set 
in. A trainee once asked me how best she could improve her translation skills. I recalled my first mentor's thinking, to the effect that knowledge of the source language is in fact secondary to knowledge of the target language.

Every translator, he maintained, should engage in a little creative writing on the side, to avoid his texts becoming contaminated by what has come to be called in the trade "Translator's English". I have been acting on that advice for some years now, and I like to think my professional work has begun to reflect my efforts. My answer to my trainee? "Write, write, write." All other things being equal, there's no other way, really. To be sure, reading good literature will improve a translator's vocabulary, and is not to be ignored, but it will do nothing for that translator's ability to express himself: that can only be improved by strict self-discipline and diligent practice. A translator indeed may be born, but a good translator is made.

You ask me what is required of a translator. To begin with, of course, he must know the language in which the message is conveyed (the source language) and that in which he is to render it (the target language). His knowledge of the source language, while perhaps passive or receptive, must still be sufficient to prevent his straying into any of the great multitude of snares which lie in wait for the unwary. Of the target language his knowledge - infinitely more difficult to acquire than that of the source language and gained over the years by dint of consistent effort - must be flawless: active, creative. For ideally, should not every text he turns out read as though it had been conceived and written in that language? I say "ideally", for how many of us can claim with a straight face that our texts carry not the slightest whiff of translation? I certainly cannot. It is for that reason that I speak of constantly honing the skills of translation: perfecting them; refining them. As a corollary, I would add that a translator must be able ruthlessly to criticise his own writing.

What else? Briefly, a translator must be a walking dictionary, style book, encyclopedia, and compendium of every type of terminology imaginable. Failing that, he must have on hand an inexhaustible supply of resource material, for assistance in terminological research. And failing that, he must be able to contact someone knowledgeable who, it is hoped, will be able to answer his queries.

Reduced to its simplest terms, translation involves reading a text which has been written in one language, and committing it to paper in another. Why do I translate? Because someone seeks to understand a message which has been written in a language which he does not understand but which $I$ do. And since language barriers are as old as civilization itself, I practise one of the oldest professions known to mankind: a profession whose history is as honourable and as complex as that of any other branch of literature. My colleagues were labouring long before the dawn of the Christian era.

I practise what is also a lonely profession. Consider for a moment the nature of the translator's task. Once a text is set before him, he must withdraw himself from human contact and work out its translation. No one will sit beside him, to guide his hand or to choose his vocabulary. But, I hear you ask, can he not discuss his difficulties with his colleagues, or even with his author? Indeed. And has he not to hand any number of reference works? Perhaps. But in the definitive act of committing to paper the message which the author would convey, the translator is alone. The text he produces is his own creation.

So tell me what you do, I hear you ask, when you engage in the act of translation.

What follows is a rough description of procedure in the Direction de la traduction, ministère des Communications, gouvernement du Québec: a team of which I had the honour to be part for nineteen years.

When a translator is given a text for translation, his first duty is to study that text in depth. What does the author say? But is that what he means to say? As my colleague reads, he makes notes: here on an expression to be researched, there on a word of double or doubtful meaning. Depending on the nature of the text, this phase alone can occupy a good part of a translator's day (or week!). Once it is completed, he can finally set to work, facing yet again the challenge of which I have written above: to render flawlessly in his own language a message written in another.

How long it takes him to finish the job will depend on a number of factors: the length of the text, of course, the author's ease of selfexpression, the technical nature of the source message...

Once that job is finished, the translator must re-read his text and polish it up. It is here that his ability ruthlessly to criticize his own writing comes into play.

Once he is satisfied that he can make nothing more in the way of improvement to his text (or once his deadline has expired - usually the latter), his work is handed to a colleague, for revision.

Revision is a necessary phase: a close comparison of source text with target text. The reviser's task is to make sure there have been no errors in the original translation and, where he must, to improve the style.

Once the text has been revised, translator and reviser meet, if necessary, to discuss the changes proposed by the reviser. Who has the last word? Does it matter? Here, the primary concern is for the quality of the finished product. Where translator and reviser cannot agree as to whether or 
not a certain word should be used, or a certain construction employed, they attempt to work out a compromise, or perhaps seek out the opinion of a third colleague.

With agreement finally reached as to how the text will read, the next step is copy-correction, popularly but erroneously called "proof-reading".

This involves another comparison: between the final text and the revised copy, from which it has been typed. And it is amazing how a fresh pair of eyes can frequently pick out offensive miswritings committed by the translator and glossed over by the reviser.

Such, then, is the essence of the translation process, as I experienced it: a process which can extend anywhere from minutes to years. Through it, a professional translator's reputation can be permanently established, or his credibility destroyed for all time. Without it, dialogue between nations would be impossible; it is indispensable to dissemination of data between international societies and firms. It is the basis for countless publications. It provides material for university courses, lectures, seminars; it is the raison d'être for how many professional associations?

And it has been called the most challenging of all intellectual exercises.

\section{$* * *$}

The title of this article reflects reality. The Translation Office at the National Assembly is responsible for translating all legislation tabled in the Quebec Legislature. In my days in that office, all translation was done longhand, in pencil. Typewriters, for some reason, were machina non grata. Naturally, when I appeared on the scene, I'd never known anything else, so I didn't find it all that strange. Since that time, with the advent of computer-assisted translation, that office has become one of the best endowed in the government.

Isn't the rule to start out as a generalist then move into a speciality? Maybe, but I did it the other way round. And looking back, I wouldn't have had it any differently. Indeed, it's since become my conviction that ideally, anyone planning on a government career in translation should be able to begin that career with a couple of years in the translation office at the Direction de la législation. He'll learn how to work accurately; he'll learn whether he can take extreme pressure. Finally, he'll get a thorough grounding in the mechanics of statute law: something which, whether he moves on or stays put, will prove a valuable asset.

But I wouldn't be fair if I didn't issue two caveats: first, about that pressure: not everyone can take the kind sometimes encountered there, and who can fault them? If a translator finds he's one of these, he must look the fact square on, and not just hang in there trying to prove something: I know of no better way to court health problems. Second caveat: given the nature of "the system", and its demands on anyone working on that team, there's always the possibility that a translator's prolonged absences and unpredictable hours will affect his family. If they do, he should begin to think of a transfer (to Communications, maybe?). Because one thing's certain: the system won't change. And your family's more important than some piece of legislation that has to be tabled last week.

I look back on my days at the Assembly with gratitude: here it was that I found my life's vocation. I was extremely lucky in my mentors and in my colleagues. The team spirit was something I'd never seen before and have seldom seen since: if a job was to be done, all hands knuckled down, and if this meant labouring into the night, or giving up a week-end, so be it. In some quarters we were seen not as a staff but as a family. Work was a constant challenge; a constant learning experience. And while we worked hard, it was in the knowledge that what we were doing was of lasting importance, and appreciated. The day I finally moved on was one of the saddest in my career.

In Communications, typewriters were standard equipment; they remained so until the advent of the word processor.

During my first year in my new department, office landscaping was just becoming the rage. At about the end of my first month there, I was introduced to this brand new concept in working conditions.

I nearly resigned on the spot, and can honestly say that I've never truly adapted to landscaped offices. Translation demands enough concentration simply in the understanding of the source text and its conversion into the target text, without the additional effort of consciously blotting out the distractions created by colleagues using the telephone, typewriters clacking, people walking back and forth (and sometimes pausing for a chat outside one's cubicle), you name it. My initial misery was alleviated somewhat by the purchase of a pair of ear-plugs of the type used on industrial sites, which eventually I was able to discard, but even so... I have frequently seen it written, and heard it said, that translation is misunderstood by those in authority. Until I see my colleagues given better working conditions, I shall be forced to concur with this. A translator needs those four walls and that door.

Before I left the Assembly, I was blissfully unaware of the existence of word counts and quotas. There were far more important matters to see to than counting up how many words a 
translator turned out over a given period, or estimating how many he should turn out over that period. In this regard, life was uncomplicated whatever Cabinet threw at us, we translated: as expeditiously as possible, no questions asked, then move on to the next one.

In Communications, my eyes were opened. I'm not belittling the importance of the word count. From an administrative point of view its necessity cannot be disputed, for obvious reasons. This does not, however, prevent its being placed in the wrong perspective, or its importance being over-emphasized, often by zealous directors of translation who tend to judge their professionals on the strength of number of words translated rather than on beauty of finished product. I've always been able to translate at medium to high speed, and on the strength of this, I have, on occasion, been called "the best". On the strength of manual dexterity, no less! Far better to be called "the worst" and know that someone is actually assessing the quality.

The quota, on the other hand, is the number of words a translator or reviser is expected to translate or revise over a given period. Quotas vary according to who sets them and to where they're set - and I've seen some dillies! Who does set them? Again, bureaucrats who know not enough of what is involved in translation. Why are they set? Maybe out of something to do with cost estimates; maybe to "push" a given translator just a bit harder. Yet in this context, imposing a quota is tantamount to creating pressure for nothing. God knows, translators have enough pressure to cope with in their everyday work; all they need is to have a little more manufactured just so the end-ofthe-month figures look good. Indeed, how demoralizing it must be to have every day to take one's place in the shadow of that Damoclean threat hanging from the fluorescents: 1800 or else, buddy-boy! I've yet to be subject to this, but I sometimes wonder whether I didn't leave Communications right on time..

Because prior to my departure, I seemed to be hearing translation spoken of increasingly in terms of dollars and cents. No one in the right places seemed to take the slightest interest in promoting top quality work. Fortunately, my Communications colleagues of 19 years, being the self-starting professionals they are, need little such encouragement. All the same, how good I know they would feel to pick up some real, honest-to-God professional criticism of their work: the occasional remark from on high about how well a certain text was translated; what a feeling the translator had for his or her work, and so on. This, I know, would have a far more positive and stimulating effect on morale than those silly impersonal statements (are they still being distributed? with the same misguided fervour?) telling the staff members how many hours of the past month they spent collectively translating, revising or drinking coffee.

$$
* * * *
$$

Nec Plus Ultra is not just the name of a very pleasant and expensive unwinding fluid. It's also my designation for that special project which comes to everyone but once - and then only if he's lucky - in his professional career. You know the kind I mean: It grabs you from the outset; for any number of reasons, you become attached to it to the point of devotion - not to say obsession and for months, nay years, you pour all your talent and energy into it. Once it is completed, the realization comes that there will never be another like it.

My Nec Plus Ultra was without a doubt the revision of the translation of the Final Report of the Civil Code Revision Office. Over the better part of four years (1973 to 1977), I lived, ate, breathed and dreamed Civil Code Revision; I revised and translated over two million words; I met a lot of very talented and exciting people; I learned much; I lived some of the most demoralizing moments of my career, and some of the most thrilling. I received many flattering compliments on the work done by my team... and I never heard one gripe about how much it cost...

$$
* * *
$$

If I recall my time at the Assembly with gratitude, my years at Communications are recalled with a sense - possibly misplaced - of having made a contribution and of having enjoyed making it. Few were the mornings I didn't look forward to coming to work, and the stimulus lay in never knowing what my next assignment would be. I was fortunate in receiving perhaps more than my share of what we called prestige publications for translation - again, the constant challenge, the constant learning experience - and doubly fortunate in having some of the best revisers in the Province to back up my work.

A late friend and colleague spoke long ago of the value of being able to look back at the end of the day and feel you've done something. Throughout my government career, I did everything I could to live by this. Certainly I had more than ample opportunity.

Some time back, a Torontonian colleague published his recollections of ten years' work into French in the Queen City. I've no intention of launching into a critique of my ex-colleague's work; suffice it to say that while I agree with some of its points, I disagree with most. 
But then, his business is his business and my business is mine.

At the close of his work, the author describes how he quit the profession - in his own words, he spewed it forth in a mighty cataract upon the undeserving lawns of Glendon Campus (noble profession! ignoble fate!). When finally he takes leave of his reader, it is in a state of mixed emotions: joy, terror, fear...

Now I must take leave of my own reader. For I have recorded some of what I have observed over 27 years of practice: not all, by any means, but a fraction of the essential.

Unlike my Torontonian colleague, however, as I leave my reader I do not leave my profession. How could I? For while like a true Gilbertian Peer, I

make no pretence

to intellectual eminence

or scholarship sublime,

yet I remain hooked - and always shall. The lawns of Glendon need fear no cataract of mine.

R. CLIVE MEREDITH Sainte-Foy, Québec, Canada 